\title{
Desulfobaculum xiamenensis gen. nov., sp. nov., a member of the family Desulfovibrionaceae isolated from marine mangrove sediment
}

Correspondence

Lingwei Ruan

ruanlingwei@yahoo.com.cn
Chao Zhao, ${ }^{1,2}$ Zhaoming Gao, ${ }^{1}$ Qiwei Qin, ${ }^{3}$ Fuying $\mathrm{Li}^{1}$ and Lingwei Ruan ${ }^{1}$

${ }^{1}$ Key Laboratory of Marine Biogenetic Resources, Third Institute of Oceanography, State Oceanic Administration (SOA), Xiamen 361005, PR China

${ }^{2}$ Institute of Bioenergy and College of Food Science, Fujian Agriculture and Forestry University, Fuzhou 350002, PR China

${ }^{3}$ Laboratory of Marine Biology, South China Sea Institute of Oceanology, The Chinese Academy of Sciences, Guangzhou 510301, PR China

\begin{abstract}
A taxonomic study was carried out on strain $\mathrm{P}^{\top}$, which was isolated from mangrove sediment samples collected from Qinglan Port (Hainan, China). Cells were curved rods, that were motile, with a single polar flagellum. The strain was non-spore-forming with a cell size of $0.6 \times 1.5-$ $2.2 \mu \mathrm{m}$. Catalase and oxidase activities were not detected. Growth was observed in the temperature range $22-44{ }^{\circ} \mathrm{C}$ (optimum, $35-40{ }^{\circ} \mathrm{C}$ ) and $\mathrm{pH}$ range 5.5-8.5 (optimum, $\mathrm{pH} 7.0$ ). $\mathrm{NaCl}$ was required for growth and tolerated at up to $3.5 \%(\mathrm{w} / \mathrm{v})$ (optimum, $0.5 \%$ ). Strain $\mathrm{P} 1^{\top}$ utilized hydrogen, succinate, L-malate, citrate, oxalate, DL-lactate, pyruvate, or cysteine as electron donors, and sulfate or sulfite as electron acceptors. Fermentation products from pyruvate were acetate, $\mathrm{H}_{2}$ and $\mathrm{CO}_{2}$. Phylogenetic analyses based on 16S rRNA gene sequences showed that strain $\mathrm{P} 1^{\top}$ formed a distinct evolutionary lineage within the family Desulfovibrionaceae. Strain $\mathrm{P} 1^{\top}$ was most closely related to members of the genera Desulfovibrio (92.0-94.3\% 16S rRNA gene sequence similarity), Desulfocurvus (91.1\%), Bilophila (87.9\%) and Lawsonia (86.0\%) of the family Desulfovibrionaceae. The DNA G $+\mathrm{C}$ content of strain $\mathrm{P}^{\top}$ was $64.5 \mathrm{~mol} \%$ and the major cellular fatty acids were iso- $\mathrm{C}_{15: 0}(18.8 \%)$, anteiso- $\mathrm{C}_{15: 0}(5.0 \%), \mathrm{C}_{16: 0}(14.2 \%)$ and iso$\mathrm{C}_{17: 1} \omega 9 c(24.4 \%)$. The predominant menaquinone was MK-7 (97\%). Major polar lipids were phosphatidylcholine, phosphatidylethanolamine and phosphatidylglycerol. Strain $\mathrm{P}^{\top}$ was distinguishable from members of phylogenetically related genera by differences in several phenotypic properties. On the basis of the phenotypic and phylogenetic data, strain $\mathrm{P}^{\top}$ represents a novel species of a new genus, for which the name Desulfobaculum xiamenensis gen. nov., sp. nov. is proposed. The type strain of Desulfobaculum xiamenensis is $\mathrm{P}^{\top}{ }^{\top}(=\mathrm{CGMCC}$ $1.5166^{\top}=$ DSM $24233^{\top}$ ).
\end{abstract}

In anaerobic environments, sulfate-reducing bacteria obtain their energy by oxidizing organic compounds or molecular hydrogen while reducing sulfates to sulfides, especially to hydrogen sulfide (Peck, 1993; Widdel \& Hansen, 1992). Bacterial sulfate reduction is an important process of mineralization of organic matter in anoxic environments, especially in marine and hypersaline systems (Ollivier et al.,

Abbreviations: ASW, artificial sea water; PC, phosphatidylcholine; PE, phosphatidylethanolamine; PG, phosphatidylglycerol.

The GenBank/EMBL/DDBJ accession numbers for the 16S rRNA gene sequence and dsr gene sequence of strain $\mathrm{P}^{\top}$ are HO697913 and JF742988, respectively.

Three supplementary figures are available with the online version of this paper.
1994). Mangrove ecosystems play an important role in maintaining and improving biological environments, and are home to a large, unexplored microbial diversity (Chang et al., 2009; Li \& Lee, 1997; Liao et al., 2009). In an investigation of a cellulolytic consortium, we isolated a novel sulfate-reducing strain, designated strain $\mathrm{P} 1^{\mathrm{T}}$, from typical mangrove forest sediment samples. Comparative 16S rRNA gene sequence analysis indicated that strain $\mathrm{P}^{\mathrm{T}}$ formed a deep branch within the family Desulfovibrionaceae. The family Desulfovibrionaceae was first proposed by Kuever et al. (2005) based on phylogenetic analysis of 16S rRNA gene sequences, and contains four genera: Desulfovibrio, Desulfocurvus, Bilophila and Lawsonia. In this study the exact taxonomic position of strain $\mathrm{P}^{\mathrm{T}}$ was determined by a polyphasic approach. 
The mangrove sediment samples were collected from Qinglan Port area (Hainan, China). Strain $\mathrm{P} 1^{\mathrm{T}}$ was isolated from a culture enriched with filter paper as the sole carbon source under a gas phase of $\mathrm{CO}_{2} / \mathrm{N}_{2}$. The streak-plate procedure was repeated several times before strain $\mathrm{P} 1^{\mathrm{T}}$ was obtained. Defined YTBC medium was used for the enrichment culture, isolation and general physiological characterization of the strain, and contained [per litre artificial seawater (ASW)]: yeast extract $1.0 \mathrm{~g}$, tryptone $5.0 \mathrm{~g}$, casein acid $5.0 \mathrm{~g}$, beef extract $5.0 \mathrm{~g}, \mathrm{~K}_{2} \mathrm{HPO}_{4} 1.0 \mathrm{~g}$, $\mathrm{NH}_{4} \mathrm{NO}_{3} 1.0$ g, $\mathrm{Na}_{2} \mathrm{WO}_{4} .2 \mathrm{H}_{2} \mathrm{O} 0.1 \mathrm{mg}, \mathrm{Na}_{2} \mathrm{SeO}_{3} .5 \mathrm{H}_{2} \mathrm{O}$ $0.1 \mathrm{mg}, \mathrm{NiCl}_{2} \cdot 6 \mathrm{H}_{2} \mathrm{O} 7.5 \mathrm{mg}$, resazurin $1.0 \mathrm{mg}$ (for anaerobic), cysteine $\mathrm{HCl} 0.25 \mathrm{~g}$ (for anaerobic), $\mathrm{Na}_{2} \mathrm{~S} .9 \mathrm{H}_{2} \mathrm{O}$ $0.25 \mathrm{~g}$ (for anaerobic). ASW contained (per litre distilled water): $\mathrm{NaCl} 5 \mathrm{~g}, \mathrm{MgCl}_{2} .6 \mathrm{H}_{2} \mathrm{O} 0.75 \mathrm{~g}, \mathrm{MgSO}_{4} \cdot 7 \mathrm{H}_{2} \mathrm{O}$ $6.0 \mathrm{~g}, \mathrm{NaHCO}_{3} 0.05 \mathrm{~g}, \mathrm{CaCl}_{2} \cdot 2 \mathrm{H}_{2} \mathrm{O} 0.1 \mathrm{~g}, \mathrm{KCl} 0.1 \mathrm{~g}$, $\mathrm{KH}_{2} \mathrm{PO}_{4} 0.1 \mathrm{~g}$. The $\mathrm{pH}$ of YTBC medium was adjusted to pH 7.0-7.5 with $2 \mathrm{M} \mathrm{NaOH}$. The reference strain Desulfovibrio senezii DSM $8436^{\mathrm{T}}$ was obtained from the DSMZ (Braunschweig, Germany) and incubated as described previously (Tsu et al., 1998).

Gram staining was carried out according to Cowan \& Steel (1993). Cell morphology was examined by light microscopy (TE2000 S/U; Nikon) and transmission electron microscopy (JEM-1230; JEOL) after cultivation at $35{ }^{\circ} \mathrm{C}$ for $48 \mathrm{~h}$. Catalase and oxidase activities were determined by using an Oxidase Reagent kit (bioMérieux) according to the manufacturer's instructions. The physiological characterization of strain $\mathrm{P}^{\mathrm{T}}$ included determination of the temperature, $\mathrm{pH}$ and salinity ranges that allowed bacterial growth. Substrate utilization was investigated by growing strain $\mathrm{P}^{\mathrm{T}}$ in YTBC medium containing $1 \%(\mathrm{w} / \mathrm{v})$ of each of the following substrates: cellobiose, D-glucose, xylose, arabinose, maltose, mannose, mannitol, trehalose, sorbitol, lactose, fructose, starch, raffinose, rhamnose, sucrose, galactose and glycerol. Oxygen was tested as the electron acceptor in liquid and solid YTBC media. Fumarate, nitrate, sulfate, sulfite, thiosulfate $(20 \mathrm{mM}$ each $)$ and elemental sulfur $\left(20 \mathrm{mg} \mathrm{ml}^{-1}\right)$ were tested as alternate electron acceptors by replacing sulfate in the growth medium. Utilization of $\mathrm{H}_{2}$ as an electron donor was determined in the presence or absence of acetate $(5 \mathrm{mM})$ as an organic carbon source under an $\mathrm{H}_{2} / \mathrm{CO}_{2}$ atmosphere. Utilization of electron donors by the isolates was investigated by using acetate, DL-lactate, pyruvate, Casamino acids, cysteine, yeast extract, succinate, L-malate, citrate, oxalate, formate, propionate, butyrate, D-glucose, methanol and ethanol at a final concentration of $20 \mathrm{mM}$ each. Fermentative growth was tested in the YTBC medium. These results are given in the genus and species description, Table 1 and Fig. S1 (available in IJSEM Online).

Escherichia coli $\mathrm{DH} 5 \alpha$, used as the host strain for recombinant plasmids, was grown in LB medium ( $1 \%$ tryptone, $0.5 \%$ yeast extract, $1 \% \mathrm{NaCl}, \mathrm{pH} 7.0)$ at $37{ }^{\circ} \mathrm{C}$. pMD18-T (TaKaRa Biotechnology) was used as a cloning vector for PCR products. The $16 \mathrm{~S}$ rRNA gene fragment was amplified by using universal $16 \mathrm{~S}$ rRNA primers $27 \mathrm{~F}$ and $1492 \mathrm{R}$
(Weisburg et al., 1991). The purified PCR product was cloned into $\mathrm{pMD} 18-\mathrm{T}$ and sequenced with M13 primers by Invitrogen Biotechnology. The almost complete $16 \mathrm{~S}$ rRNA gene sequence $(1471 \mathrm{nt})$ of strain $\mathrm{P}^{\mathrm{T}}$ was obtained and analysed using BLAST searches against the GenBank and EzTaxon databases (Chun et al., 2007). The 16S rRNA gene sequences of closely related taxa obtained from the EzTaxon database were aligned. The phylogenetic tree was constructed by using the neighbour-joining method with MEGA 4.0 software (Tamura et al., 2007). The topology of the tree was evaluated by performing a bootstrap analysis using 1000 replications. Phylogenetic analysis showed strain $\mathrm{P}^{\mathrm{T}}$ formed a distinct evolutionary lineage within the family Desulfovibrionaceae and placed it in a phylogenetic position most closely related to the genera Desulfovibrio and Desulfocurvus (Fig. 1). The closest relatives included Desulfovibrio senezii DSM $8436^{\mathrm{T}}$, Desulfovibrio bizertensis $\mathrm{MB}^{\mathrm{T}}$ and Desulfocurvus vexinensis $\mathrm{VNs} 36^{\mathrm{T}}$ with gene sequence similarities of $94.3 \%, 92.0 \%$ and $91.1 \%$, respectively. Although the branching of strain $\mathrm{P}^{\mathrm{T}}$ with species of the genus Desulfovibrio in the phylogenetic tree was not supported strongly by bootstrap analysis, the trees generated with the distance matrix by using maximum-likelihood methods showed the same topology (data not shown). Of the sequences from recognized species, strain $\mathrm{P}^{\mathrm{T}}$ was most closely related to those from the genera Desulfovibrio (92.0-94.3\% 16S rRNA gene sequence similarity), Desulfocurvus (91.1\%), Bilophila (87.9\%) and Lawsonia (86.0\%), of the family Desulfovibrionaceae. All of the 16S rRNA gene sequence divergences between strain $\mathrm{P} 1^{\mathrm{T}}$ and recognized species were greater than $5.7 \%$, and the distinct phylogenetic relationships revealed that strain $\mathrm{P}^{\mathrm{T}}$ could not be assigned to any of the recognized genera. These relatively low levels of $16 \mathrm{~S}$ rRNA gene sequence similarity with closely related genera suggested that strain $\mathrm{P}^{\mathrm{T}}$ may represent a novel species of a new genus.

For further phylogenetic analysis of strain $\mathrm{P}^{\mathrm{T}}$, the dissimilatory sulfite reductase gene $(d s r)$ of the strain was sequenced using the method described by KarkhoffSchweizer et al. (1995). The sequences were aligned using CLUSTAL W version 1.8 (Macintosh). Phylogenetic analyses were performed by the maximum-likelihood method by MOLPHY version 2.3b (UNIX) (Adachi \& Hasegawa, 1996). The local bootstrap probabilities were calculated as the statistical confidences of the tree branches (Hasegawa \& Kishino, 1994). The partial sequence of the $d s r$ gene of strain $\mathrm{P} 1^{\mathrm{T}}$ was determined. Phylogenetic analysis based on $d s r$ gene sequences showed that strain $\mathrm{P} 1^{\mathrm{T}}$ was related most closely to 'Bacterium AR1201' (87\% sequence similarity). Its closest recognized relatives were Desulfovibrio aminophilus, DSM $12245^{\mathrm{T}}$, and Desulfovibrio longus, SEBR $2582^{\mathrm{T}},(79 \%$ and $78 \% d s r$ gene sequence similarity, respectively). The $d s r$ gene sequence similarity between strain $\mathrm{P}^{\mathrm{T}}$ and the type strain of Desulfovibrio senezii, DSM $8436^{\mathrm{T}}$, was $87.7 \%$ in this study (data not shown). On the basis of Dsr amino acid sequence analysis, strain $\mathrm{P}^{\mathrm{T}}$ was also closely related to species of the genus Desulfovibrio (Fig. S2). 
Table 1. Characteristics that differentiate strain $\mathrm{P}^{\top}$ from related genera of the family Desulfovibrionaceae

Taxa: 1, Desulfobaculum xiamenensis gen. nov., sp. nov. P1 ${ }^{\mathrm{T}}$; 2, Desulfovibrio (data from Devereux et al., 1990; Dzierzewicz et al., 1996; Gebhart et al., 1993; Kuever et al., 2005; Postgate \& Campbell, 1966); 3, Desulfocurvus (Klouche et al., 2009); 4, Bilophila (Baron et al., 1989; Kuever et al., 2005; McOrist et al., 2001); 5, Lawsonia (Kuever et al., 2005; McOrist et al., 1995). NR, Not reported; +, present, observed in all species; -, not present, not observed in all species; \pm , variable; $\mathrm{W}$, weakly present; SP, single polar flagellum; LO, lophotrichous flagellum; DV, desulfoviridin; SA, strictly anaerobic; PC, phosphatidylcholine; PE, phosphatidylethanolamine; PG, phosphatidylglycerol

\begin{tabular}{|c|c|c|c|c|c|}
\hline Characteristic & 1 & 2 & 3 & 4 & 5 \\
\hline \multicolumn{6}{|l|}{ Morphology: } \\
\hline Rod-shaped & + & - & - & + & - \\
\hline Vibrio-shaped & - & + & + & - & + \\
\hline Flagellum & SP & $\mathrm{SP} / \mathrm{LO}$ & SP & - & - \\
\hline Cell motility & + & + & + & - & - \\
\hline Catalase & - & - & - & + & NR \\
\hline $\mathrm{O}_{2}$ metabolism & SA & SA & SA & SA & Microaerophilic \\
\hline Sulfite reductase & DV & DV & - & $\mathrm{w}$ & NR \\
\hline Major menaquinone & MK-7 & MK-6 or MK- $6\left(\mathrm{H}_{2}\right)$ & NR & $\mathrm{NR}$ & NR \\
\hline Size $(\mu \mathrm{m})$ & $0.6 \times 2.0-2.2$ & $0.2-1.5 \times 2.5-10.0$ & $0.5 \times 3.0-5.0$ & $0.7-1.1 \times 1-10$ & $0.3-0.4 \times 1.5-2.0$ \\
\hline \multicolumn{6}{|l|}{ Growth conditions: } \\
\hline $\mathrm{NaCl}$ requirement & + & \pm & - & - & - \\
\hline Optimum temperature $\left({ }^{\circ} \mathrm{C}\right)$ & $35-40$ & $30-37$ & 37 & 35 & $35-37$ \\
\hline $\mathrm{pH}$ range & $5.0-8.5$ & 7.2 & $5.0-9.0$ & $\mathrm{NR}$ & NR \\
\hline \multicolumn{6}{|l|}{$\begin{array}{l}\text { Electron donors and carbon } \\
\text { sources: }\end{array}$} \\
\hline Hydrogen & + & + & - & NR & NR \\
\hline Formate & - & \pm & + & + & - \\
\hline Acetate & + & \pm & - & + & - \\
\hline Ethanol & - & \pm & - & + & NR \\
\hline Lactate & + & + & + & + & - \\
\hline Pyruvate & + & + & + & + & - \\
\hline Fumarate & + & + & - & $\mathrm{NR}$ & NR \\
\hline Succinate & + & - & - & $\mathrm{NR}$ & NR \\
\hline Malate & + & + & - & $\mathrm{NR}$ & NR \\
\hline \multicolumn{6}{|l|}{ Electron acceptors: ${ }^{*}$} \\
\hline Sulfate & + & + & + & - & \\
\hline Sulfite & + & + & + & + & \\
\hline Sulfur & - & - & - & $\mathrm{NR}$ & \\
\hline Thiosulfate & - & + & + & + & \\
\hline Nitrate & - & \pm & - & + & \\
\hline Major fatty acids & $\begin{array}{l}\text { iso- } \mathrm{C}_{15: 0}, \mathrm{C}_{16: 0} \\
\quad \text { iso- } \mathrm{C}_{17: 1} \omega 9 c\end{array}$ & $\begin{array}{l}\text { iso- } C_{15: 0}, \text { iso- } C_{17: 0} \\
\quad \text { iso- } C_{17: 1} \omega 9 c\end{array}$ & NR & $\begin{array}{c}\text { iso- } \mathrm{C}_{15: 0}, \mathrm{C}_{16: 0}, \mathrm{C}_{18: 1} \omega 9 c \\
\mathrm{C}_{19: 0} \text { cyclo } \omega 9 c\end{array}$ & NR \\
\hline Major polar lipids & PC, PE, PG & PE, PG & NR & $\mathrm{NR}$ & NR \\
\hline DNA G $+\mathrm{C}$ content $(\mathrm{mol} \%)$ & 64.5 & $47-60$ & 67.2 & 59.2 & 34 \\
\hline Isolation source & $\begin{array}{l}\text { Mangrove } \\
\text { sediments }\end{array}$ & $\begin{array}{c}\text { Freshwater and } \\
\text { marine }\end{array}$ & $\begin{array}{l}\text { Deep saline } \\
\text { aquifer }\end{array}$ & $\begin{array}{c}\text { Freshwater or clinical } \\
\text { isolates }\end{array}$ & Porcine \\
\hline
\end{tabular}

${ }^{*}$ Members of the genus Lawsonia exhibit no sulfate reduction.

Genomic DNA was extracted and purified using the method described by Syn \& Swarup (2000). The DNA G + C content was determined with HPLC of the deoxyribonucleosides as described by Mesbah \& Whitman (1989). The G+C content of the genomic DNA of strain $\mathrm{P}^{\mathrm{T}}$ was $64.5 \pm$ $1.0 \mathrm{~mol} \%$, which was similar to values reported for the genera Desulfovibrio (46-60 mol\%) and Desulfocurvus (67.2 mol\%), but differed by more than $5 \mathrm{~mol} \%$ from values reported for the genera Bilophila $(59.2 \mathrm{~mol} \%)$ and Lawsonia (34 mol\%).
Fatty acids of $0.2 \mathrm{~g}$ freeze-dried whole cells grown in YTBC liquid medium at $35{ }^{\circ} \mathrm{C}$ for $48 \mathrm{~h}$ were extracted, saponified and esterified, followed by GC analysis of the fatty acid methyl esters according to the instructions of the MIDI system (Sasser, 1990). The major fatty acids of strain $\mathrm{P}^{\mathrm{T}}$ were iso- $\mathrm{C}_{15: 0}(18.8 \%)$, anteiso- $\mathrm{C}_{15: 0}(5.0 \%), \mathrm{C}_{16: 0}$ $(14.2 \%)$ and iso- $\mathrm{C}_{17: 1} \omega 9 c(24.4 \%)$. Minor amounts of $\mathrm{C}_{14: 0}(4.3 \%), \mathrm{C}_{16: 1} \omega 7 c$ and/or $\mathrm{C}_{16: 1} \omega 6 c(4.3 \%)$, iso- $\mathrm{C}_{17: 0}$ $(4.2 \%)$, anteiso- $\mathrm{C}_{17: 1} \omega 9 c(2.9 \%), \mathrm{C}_{18: 0}(1.9 \%), \mathrm{C}_{18: 1} \omega 9 c$ $(3.4 \%)$ and $\mathrm{C}_{18: 1} \omega 7 c(4.1 \%)$ were also found in strain 


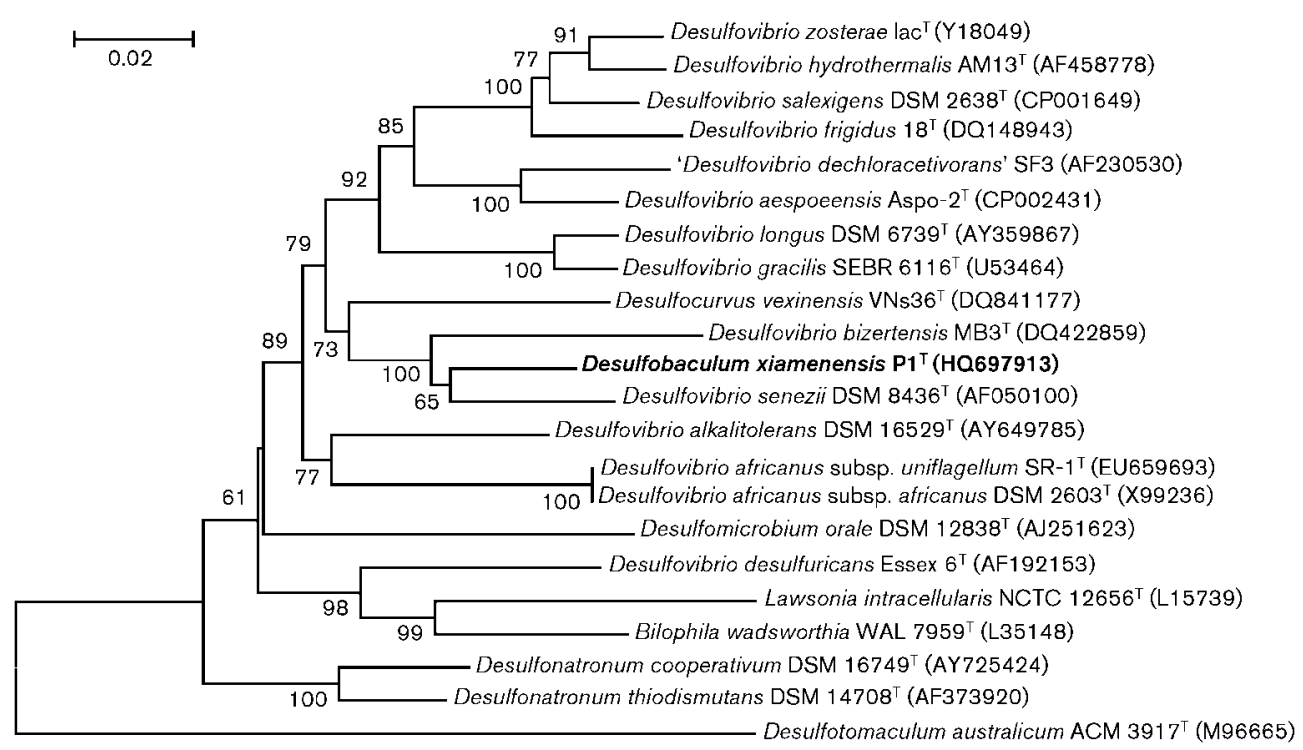

Fig. 1. Unrooted neighbour-joining tree of strain $P 1^{\top}$ and related genera based on $16 S$ rRNA gene sequences. Numbers at nodes represented the levels of bootstrap support (\%) based on a neighbour-joining analysis of 1000 resampled datasets. GenBank accession numbers of $16 \mathrm{~S}$ rRNA gene sequences are given in the parentheses. Bar, 0.02 nt substitution rate $\left(K_{\text {nuc }}\right)$ units.

$\mathrm{P} 1^{\mathrm{T}}$. These data differentiated strain $\mathrm{P} 1^{\mathrm{T}}$ from members of the genera Desulfovibrio and Bilophila. The major cellular fatty acids of members of the genus Desulfovibrio are iso$\mathrm{C}_{15: 0}$, iso- $\mathrm{C}_{17: 0}$ and iso- $\mathrm{C}_{17: 1} \omega 9 c$ (Kohring et al., 1994; Taylor \& Parkes, 1983; Vainshtein et al., 1992). Fatty acid methyl ester analysis of the genus Bilophila revealed a unique series of whole-cell fatty acids, which included iso- $\mathrm{C}_{15: 0}$, $\mathrm{C}_{16: 0}, \mathrm{C}_{18: 1} \omega 9 c$ and $\mathrm{C}_{19: 0}$ cyclo $\omega 9 c$ (Baron et al., 1989).

The presence of cytochromes and sulfite reductase (desulfoviridin) was measured according to the method of Badziong et al. (1978). Visible absorption spectra of a cellfree extract of strain $\mathrm{P}^{\mathrm{T}}$ showed the presence of redox potential cytochrome $c_{3}$ with absorption peaks at 522 and 550 in the dithionite reduced form. The characteristic absorption band of desulfoviridin (the bisulfite reductase characteristic of the genus Desulfovibrio) at about $630 \mathrm{~nm}$ was also detected in the cell-free extract of strain $\mathrm{P}^{\mathrm{T}}$. The characteristic absorption band of desulfoviridin was not detected in the cell-free extract of Desulfocurvus vexinensis $\mathrm{VNs}^{\mathrm{T}}{ }^{\mathrm{T}}$ (Klouche et al., 2009).

Analysis of respiratory quinones was carried out by the Identification Service and Dr Brian Tindall, DSMZ, Braunschweig. Germany. For polar lipid analysis, cell biomass of strain $\mathrm{P}^{\mathrm{T}}$ and Desulfovibrio senezii DSM $8436^{\mathrm{T}}$ was obtained from cultures grown in YTBC medium at $35{ }^{\circ} \mathrm{C}$ for $48 \mathrm{~h}$. Cellular polar lipids were extracted according to procedures described by Yassin et al. (1993), separated on silica gel 60 plates (Merck) by using TLC, and identified according to their reactions with the phosphate spray reagent of Dittmer and Lester (Dittmer \& Lester, 1964). The predominant respiratory quinone of $\mathrm{P}^{\mathrm{T}}$ was MK-7 (97\%), and a minor amount of MK-6 (3\%) was detected. However, all recognized strains of the genus Desulfovibrio contain MK-6 or MK-6 $\left(\mathrm{H}_{2}\right)$ as the major menaquinone (Collins \& Weddel, 1986). The polar lipid profiles of strain $\mathrm{P}^{\mathrm{T}}$ mainly consisted of phosphatidylcholine $(\mathrm{PC})$, phosphatidylethanolamine $(\mathrm{PE})$ and phosphatidylglycerol (PG). The major phospholipids of Desulfovibrio senezii DSM $8436^{\mathrm{T}}$ were PE and PG. The obvious difference between strain $\mathrm{P}^{\mathrm{T}}$ and Desulfovibrio senezii DSM $8436^{\mathrm{T}}$ was the presence of $\mathrm{PC}$ in strain $\mathrm{P}^{\mathrm{T}}$ (Fig. S3). Other species of the genus Desulfovibrio exhibited a phospholipid profile with PE or PG as the major phospholipid (Makula \& Finnerty, 1974). The type strain of the type species of the genus Desulfovibrio (Desulfovibrio desulfuricans ATCC $29577^{\mathrm{T}}$ ) exhibited a phospholipid pattern typical of Gramnegative bacteria with PE comprising the major phospholipid (Makula \& Finnerty, 1974).

A comparison of the main characteristics between strain $\mathrm{P}^{\mathrm{T}}$ and the type strains of related species is given in Table 1. Although strain $P 1^{\mathrm{T}}$ is most closely related to members of the genus Desulfovibrio, with the highest similarity to Desulfovibrio senezii DSM $8436^{\mathrm{T}}(94.3 \%)$, it cannot be affiliated to the genus Desulfovibrio due to the obvious differences of major menaquinone, major fatty acids and polar lipid components between strain $\mathrm{P}^{\mathrm{T}}$ and members of the genus Desulfovibrio. In addition, strain $\mathrm{P}^{\mathrm{T}}$ could be distinguished from the genus Desulfocurvus based on electron donors used and the presence of sulfite reductase. Cell motility by means of a single polar flagellum, negative catalase activity, and the presence of sulfite reductase differentiated strain $\mathrm{P}^{\mathrm{T}}$ from members of the genera Bilophila and Lawsonia. Overall, the low 16S rRNA gene sequence similarity, together with differences in chemotaxonomic, physiological 
and biochemical properties, indicated that strain $\mathrm{P} 1^{\mathrm{T}}$ represented a novel species of a new genus, for which the name Desulfobaculum xiamenensis gen. nov., sp. nov. is proposed.

\section{Description of Desulfobaculum gen. nov.}

Desulfobaculum (De.sul.fo.ba'cu.lum. L. pref. de from; L. n. sulfur sulfur; L. masc. n. baculum, a stick or rod; N.L. masc. n. Desulfobaculum a rod sulfate-reducing bacterium).

Cells are Gram-stain-negative rods. Oxidase- and catalasenegative. Obligately anaerobic, mesophilic and moderately halophilic bacteria with growth at $\mathrm{pH} 5.0-8.5$. The predominant fatty acids are iso- $\mathrm{C}_{15: 0}, \mathrm{C}_{16: 0}$ and iso$\mathrm{C}_{17: 1} \omega 9 \mathrm{c}$. The predominant respiratory quinone is MK-7. The genus is assigned phylogenetically to the family Desulfovibrionaceae in the order Desulfovibrionales. The only currently known strain was isolated from offshore mangrove sediment. The type species is Desulfobaculum xiamenensis.

\section{Description of Desulfobaculum xiamenensis sp. nov.}

Desulfobaculum xiamenensis (xi.a.men.en'sis. L. masc. adj. xiamenensis of or belonging to Xiamen, the place of isolation).

Shows the following characteristics in addition to those given in the genus description above. Cells are short rods (1.5-2.2 $\mu \mathrm{m}$ long and $0.6 \mu \mathrm{m}$ wide), non-spore-forming, and motile by means of a single polar flagellum. Grows at temperatures of $22-44{ }^{\circ} \mathrm{C}$ (optimum, $35-40{ }^{\circ} \mathrm{C}$ ) and at $\mathrm{pH}$ 5.5-8.5 (optimum, $\mathrm{pH}$ 7.0). Grows in the presence of $0.2-$ $3.5 \%(\mathrm{w} / \mathrm{v}) \mathrm{NaCl}$ (optimum, $0.5 \%)$. Utilizes cellobiose and galactose, but not D-glucose, xylose, arabinose, maltose, mannose, mannitol, trehalose, sorbitol, lactose, fructose, starch, raffinose, rhamnose, sucrose or glycerol. Grows on sulfate or sulfite as electron acceptors, but does not grow on elemental sulfur, thiosulfate, nitrate, or nitrite as electron acceptors. Grows on acetate, succinate, L-malate, citrate, oxalate, DL-lactate, pyruvate, cysteine, Casamino acids and yeast extract with sulfate or sulfite as electron acceptor. Does not use formate, ethanol, propionate, butyrate or methanol as electron donors. Ferments acetate, $\mathrm{H}_{2}$ and $\mathrm{CO}_{2}$ from pyruvate. Desulfoviridin and $c$-type cytochromes are present. Major phospholipid species are PC, PE and PG.

The type strain, $\mathrm{P} 1^{\mathrm{T}}\left(=\right.$ CGMCC $1.5166^{\mathrm{T}}=$ DSM $\left.24233^{\mathrm{T}}\right)$, was isolated from mangrove sediment samples from Qinglan Port in Hainan Island, China. The DNA G +C content of the type strain is $64.5 \mathrm{~mol} \%$.

\section{Acknowledgements}

This work was supported by the Marine Scientific Research Foundation for Public Sector Program, grant numbers 200805050 and 201105027.

\section{References}

Adachi, J. \& Hasegawa, M. (1996). Computer science monographs, no. 28. MOLPHY Version 2.3. - Programs for molecular phylogenetics based on maximum likelihood. Tokyo: Institute of Statistical Mathematics.

Badziong, W., Thauer, R. K. \& Zeikus, J. G. (1978). Isolation and characterization of Desulfovibrio growing on hydrogen plus sulfate as the sole energy source. Arch Microbiol 116, 41-49.

Baron, E. J., Summanen, P., Downes, J., Roberts, M. C., Wexler, H. \& Finegold, S. M. (1989). Bilophila wadsworthia, gen. nov. and sp. nov., a unique gram-negative anaerobic rod recovered from appendicitis specimens and human faeces. J Gen Microbiol 135, 3405-3411.

Chang, B. V., Lu, Z. J. \& Yuan, S. Y. (2009). Anaerobic degradation of nonylphenol in subtropical mangrove sediments. J Hazard Mater 165, 162-167.

Chun, J., Lee, J. H., Jung, Y., Kim, M., Kim, S., Kim, B. K. \& Lim, Y. W. (2007). EzTaxon: a web-based tool for the identification of prokaryotes based on $16 \mathrm{~S}$ ribosomal RNA gene sequences. Int J Syst Evol Microbiol 57, 2259-2261.

Collins, M. D. \& Weddel, F. (1986). Respiratory quinones of sulphatereducing and sulphur-reducing bacteria: a systematic investigation. Syst Appl Microbiol 8, 8-18.

Cowan, S. T. \& Steel, K. J. (1993). Manual for the Identification of Medical Bacteria, 3rd edn. Edited by G. I. Barrow \& R. K. A. Feltham. Cambridge: Cambridge University Press.

Devereux, R., He, S. H., Doyle, C. L., Orkland, S., Stahl, D. A., LeGall, J. \& Whitman, W. B. (1990). Diversity and origin of Desulfovibrio species: phylogenetic definition of a family. J Bacteriol 172, 3609-3619.

Dittmer, J. C. \& Lester, R. L. (1964). A simple specific spray for the detection of phospholipids on thin-layer chromatograms. J Lipid Res $15,126-127$.

Dzierzewicz, Z., Cwalina, B., Kurkiewicz, S., Chodurek, E. \& Wilczok, T. (1996). Intraspecies variability of cellular fatty acids among soil and intestinal strains of Desulfovibrio desulfuricans. Appl Environ Microbiol 62, 3360-3365.

Gebhart, C. J., Barns, S. M., McOrist, S., Lin, G. F. \& Lawson, G. H. (1993). Ileal symbiont intracellularis, an obligate intracellular bacterium of porcine intestines showing a relationship to Desulfovibrio species. Int J Syst Bacteriol 43, 533-538.

Hasegawa, M. \& Kishino, H. (1994). Accuracies of the simple methods for estimating the bootstrap probability of a maximumlikelihood tree. Mol Biol Evol 11, 142-145.

Karkhoff-Schweizer, R. R., Huber, D. P. W. \& Voordouw, G. (1995). Conservation of the genes for dissimilatory sulfite reductase from Desulfovibrio vulgaris and Archaeoglobus fulgidus allows their detection by PCR. Appl Environ Microbiol 61, 290-296.

Klouche, N., Basso, O., Lascourrèges, J. F., Cayol, J. L., Thomas, P., Fauque, G., Fardeau, M. L. \& Magot, M. (2009). Desulfocurvus vexinensis gen. nov., sp. nov., a sulfate-reducing bacterium isolated from a deep subsurface aquifer. Int J Syst Evol Microbiol 59, 3100-3104.

Kohring, L. L., Ringelberg, D. B., Devereux, R., Stahl, D. A., Mittelman, M. W. \& White, D. C. (1994). Comparison of phylogenetic relationships based on phospholipid fatty acid profiles and ribosomal RNA sequence similarities among dissimilatory sulfate-reducing bacteria. FEMS Microbiol Lett 119, 303-308.

Kuever, J., Rainey, F. A. \& Widdel, F. (2005). Family I. Desulfovibrionaceae fam. nov. In Bergey's Manual of Systematic Bacteriology, 2nd edn, vol. 2 (The Proteobacteria) part C (The Alpha-, Beta-, Deltaand Epsilonproteobacteria), pp. 926-943. Edited by D. J. Brenner, N. R. Krieg, J. T. Staley \& G. M. Garrity. New York: Springer.

Li, M. S. \& Lee, S. Y. (1997). Mangroves of China: a brief review. For Ecol Manage 96, 241-259. 
Liao, Q. Y., Li, J., Zhang, J. H., Li, M., Lu, Y. \& Xu, R. L. (2009). An ecological analysis of soil sarcodina at Dongzhaigang mangrove in Hainan Island, China. Eur J Soil Biol 45, 214-219.

Makula, R. A. \& Finnerty, W. R. (1974). Phospholipid composition of Desulfovibrio species. J Bacteriol 120, 1279-1283.

McOrist, S., Gebhart, C. J., Boid, R. \& Barns, S. M. (1995). Characterization of Lawsonia intracellularis gen. nov., sp. nov., the obligately intracellular bacterium of porcine proliferative enteropathy. Int J Syst Bacteriol 45, 820-825.

McOrist, A. L., Warhurst, M., McOrist, S. \& Bird, A. R. (2001). Colonic infection by Bilophila wadsworthia in pigs. J Clin Microbiol 39, 15771579.

Mesbah, M. \& Whitman, W. B. (1989). Measurement of deoxyguanosine/thymidine ratios in complex mixtures by high-performance liquid chromatography for determination of the mole percentage guanine + cytosine of DNA. J Chromatogr A 479, 297-306.

Ollivier, B., Caumette, P., Garcia, J. L. \& Mah, R. A. (1994). Anaerobic bacteria from hypersaline environments. Microbiol Rev 58, 27-38.

Peck, H. D., Jr (1993). Bioenergetic strategies of the sulfate-reducing bacteria. In The Sulfate-Reducing Bacteria: Contemporary Perspectives, pp. 41-76. Edited by J. M. Odom \& R., Jr. New York: Springer.

Postgate, J. R. \& Campbell, L. L. (1966). Classification of Desulfovibrio species, the nonsporulating sulfate-reducing bacteria. Bacteriol Rev 30 , 732-738.

Sasser, M. (1990). Identification of bacteria by gas chromatography of cellular fatty acids, MIDI Technical Note 101. Newark, DE: MIDI Inc.
Syn, C. K. \& Swarup, S. (2000). A scalable protocol for the isolation of large-sized genomic DNA within an hour from several bacteria. Anal Biochem 278, 86-90.

Tamura, K., Dudley, J., Nei, M. \& Kumar, S. (2007). MEGA4: molecular evolutionary genetics analysis (MEGA) software version 4.0. Mol Biol Evol 24, 1596-1599.

Taylor, J. \& Parkes, R. J. (1983). The cellular fatty acids of the sulphate-reducing bacteria, Desulfobacter sp., Desulfobulbus sp. and Desulfovibrio desulfuricans. J Gen Microbiol 129, 3303-3309.

Tsu, I. H., Huang, C. Y., Garcia, J. L., Patel, B. K. C., Cayol, J. L., Baresi, L. \& Mah, R. A. (1998). Isolation and characterization of Desulfovibrio senezii sp. nov., A halotolerant sulfate reducer from a solar saltern and phylogenetic confirmation of Desulfovibrio fructosovorans as a new species. Arch Microbiol 170, 313-317.

Vainshtein, M., Hippe, H. \& Kroppenstedt, R. M. (1992). Cellular fatty acid composition of Desulfovibrio species and its use in classification of sulfate-reducing bacteria. Syst Appl Microbiol 15, 554-566.

Weisburg, W. G., Barns, S. M., Pelletier, D. A. \& Lane, D. J. (1991). $16 \mathrm{~S}$ ribosomal DNA amplification for phylogenetic study. J Bacteriol 173, 697-703.

Widdel, F. \& Hansen, T. A., Jr (1992). The dissimilatory sulfate and sulfur-reducing bacteria. In The Prokaryotes, pp. 583-624. Edited by A. Balows, H. G. Trüper, M. Dworkin, W. Harder \& K. H. Schleifer. New York: Springer.

Yassin, A. F., Haggenel, B., Budzikiewicz, H. \& Schaal, K. P. (1993). Fatty acid and polar lipid composition of the genus Amycolatopsis: application of fast atom Bombardment-Mass Spectrometry to structure analysis of underivatized phospholipids. Int J Syst Bacteriol 43, 414-420. 